\title{
Pengembangan Media Pembelajaran Berbasis Google Workspace Dengan Optimalisasi Akun Belajar.id
}

\author{
Silvi Rahmawati \\ STAI DR. KHEZ MUTTAQIEN PURWAKARTA \\ zamzamsilvi016@gmail.com \\ Muhammad Ridwan Effendi \\ STAI DR. KHEZ MUTTAQIEN PURWAKARTA
}

areadone19@gmail.com

Dyah Wulandari

STAI DR. KHEZ MUTTAQIEN PURWAKARTA

dyahwulandari970@gmail.com

DOI: https://DOI.org/10.52593/pdg.03.1.01

Naskah diterima: 27 September 2021 direvisi: 28 Desember 2021 disetujui: 30 Desember 2021

\begin{abstract}
Education is one aspect that is used as a forum to shape the morals and behavior of the nation's children. Therefore, today's education requires each of its components to carry out their duties and roles well. Likewise with educators who must always develop learning both from the strategy or the media used. The objectives of this study include: (1) How to develop online learning media, (2) What are the advantages of developing online learning media, (3) What are the obstacles and solutions in developing online learning media at SMKN 2 Purwakarta. This study uses a qualitative approach with a descriptive method. The type of data used is primary and secondary data with data collection techniques using observation, interviews, and documentation. Testing the validity of the data with extended observations, triangulation, and discussions with colleagues. The theory used according to Sadirman about the teacher's role as a mediator, as well as the theory of learning media development using the ADDIE model. Based on the research results, first, the development of online learning media at SMKN 2 Purwakarta is in accordance with the ADDIE development model by optimizing the use of google workspace media with the learning.id account facility provided by the Ministry of Education and Culture. Second, the advantages of development include: Increasing effectiveness and efficiency in learning, Students are able to create something new, Encouraging students to express ideas, Encouraging teachers to be more creative, Expanding learning opportunities, Improving the quality of teaching and learning, Facilitating the formation of skills, Encouraging learning lifelong sustainability, Improving policy planning and management, Reducing the digital divide. Third, the obstacle to developing online learning media is the lack of knowledge about online learning media, while the solution is in several ways, including: Establishing the right strategy, providing training and always sharing with other school teacher friends through social media.
\end{abstract}

Keywords: teacher's role, media development, online learning

\begin{abstract}
Abstraksi
Pendidikan adalah salah satu aspek yang dijadikan sebagai wadah untuk membentuk moral dan perilaku anak bangsa. Oleh sebab itu pendidikan hari ini menuntut setiap
\end{abstract}


komponennya untuk melaksanakan tugas dan perannya dengan baik. Begitu juga dengan pendidik yang harus selalu mengembangkan pembelajaran baik dari stategi ataupun media yang digunakan. Tujuan penelitian ini antara lain: (1) Bagaimana pengembangan media pembelajaran daring, (2) Apa saja Kelebihan pengembangan media pembelajaran daring, (3) Apa saja kendala dan solusi dalam pengembangan media pembelajaran daring di SMKN 2 Purwakarta. Penelitian ini menggunakan pendekatan kualitatif dengan metode deskriptif. Jenis data yang digunakan adalah data primer dan sekunder dengan teknik pengumpulan data menggunakan observasi, wawancara, dan dokumentasi. Pengujian keabsahan data dengan perpanjangan pengamatan, trianggulasi, dan diskusi dengan teman sejawat. Adapun teori yang digunakan menurut sadirman tentang peran guru sebagai mediator, serta teori pengembangan media pembelajaran menggunakan model ADDIE. Berdasarkan hasil penelitian, pertama, Pengembangan media pembelajaran daring di SMKN 2 Purwakarta sudah sesuai dengan model pengembangan ADDIE dengan optimalisasi penggunaan media google workspace dengan fasilitas akun belajar.id yang disediakan kemendikbud. Kedua, kelebihan pengembangan antara lain: Meningkatkan efektivitas dan efisiensi dalam pembelajaran, Anak didik mampu mencipatakan sesuatu yang baru, Mendorong anak didik dalam mengekspresikan gagasan, Mendorong guru untuk lebih kreatif, Memperluas kesempatan belajar, Meningkatkan kualitas belajar mengajar, Memfasilitasi pembentukan keterampilan, Mendorong belajar sepanjang hayat berkelanjutan, Meningkatkan perencanaan kebijakan dan manajemen, Mengurangi kesenjangan digital. Ketiga, kendala pengembangan media pembelajaran daring adalah kurangnya pengetahuan tentang media pembelajaran daring sedangkan solusinya dengan beberapa cara antara lain: Menetapkan strategi yang tepat, Pengadaan pelatihan dan selalu sharing dengan teman guru sekolah lain melalui media sosial.

Kata Kunci : Peran guru, Pengembangan media, Pembelajaran daring

\section{A. Pendahuluan}

Sejak 02 Maret 2020 pertama kali diumumkan kasus positif covid-19 di Indonesia, Pemerintah mengharuskan untuk melakukan setiap aktivitas di rumah. Hal ini memberi pengaruh pada setiap aspek kehidupan, salah satunya pendidikan. Hal ini dapat dilihat dari berbagai kebijakan yang dibuat oleh pemerintah terkait pendidikan di masa pandemi, antara lain revisi surat keputusan bersama empat menteri yang telah diterbitkan tanggal 07 agustus 2020, untuk menyesuaikan pembelajaran di masa pandemi saat ini.

Salah satu kebijakan yang dibuat adalah yang tercantum dalam surat edaran nomor 36962/MPK.A/HK/2020 tentang pembelajaran secara daring dan Belajar dari rumah atau pembelajaran jarak jauh sebagai kendala dan solusi pencegahan penyebaran

\footnotetext{
${ }^{1}$ Pengelola web kemdikbud, "Kemendikbud Terbitkan Kurikulum Darurat Pada Satuan Pendidikan Dalam Kondisi Khusus," Kemdikbud.Go.Id, last modified 2020, accessed June 25, 2021, https://www.kemdikbud.go.id/main/blog/2020/08/kemendikbud-terbitkan-kurikulum-darurat-pada satuanpendidikan-dalam-kondisi-khusus.
} 
virus covid-19. Dimana pembelajaran ini dilakukan oleh peserta didik dan pendidik dengan memanfaatkan kecanggihan teknologi jaringan dan informasi untuk mengembangkan proses pembelajaran di sekolah dengan cara pembelajaran daring. Pembelajaran daring merupakan pembelajaran yang dilakukan dengan menggunakan perangkat komputer atau alat canggih lainnya dengan terhubung ke internet agar pendidik dan peserta didik dapat berkomunikasi secara aktif dalam proses pembelajaran. Dengan demikian proses pembelajaran masih bisa dilakukan dengan tanpa tatap muka, sehingga penyebaran virus bisa dicegah dan diatasi secara maksimal. $^{2}$

Pendidikan hari ini menuntut kita untuk lebih bisa berpikir secara kritis memahami akan dibawa kemana pendidikan ini. Hal tersebut menuntut kreativitas dari setiap komponen pendidikan dimana Setiap komponen pendidikan harus berperan aktif dalam pelaksanaan tugas dan fungsinya masing-masing, sehingga akan tercipta proses pendidikan yang baik dan berkualitas. Kualitas pendidikan akan dipengaruhi beberapa aspek diantaranya adalah kualitas dari proses belajar mengajar di kelas. Dimana dalam kegiatan ini akan melibatkan langsung peran pendidik dan peserta didik. Peserta didik harus mampu mengembangkan kualitas diri baik secara kemampuan, pengetahuan dan pemahaman untuk lebih jauhnya menjadi manusia yang utuh untuk dirinya ataupun lingkungannya. Hal tersebut akan terlaksana tentu dengan arahan dan peran dari pendidiknya sendiri, dimana dalam praktik pembelajaran harus mampu menarik semangat belajar siswa dengan berbagai metode dan media pembelajarannya.

Dengan adanya kebijakan pemerintah terkait pembelajaran di rumah ini, pendidik dituntut untuk melakukan tugas dan perannya sebagai pendidik, dimana guru memiliki peran yang harus dilakukan dengan baik. Peran guru dalam proses pembelajaran memiliki tingkat urgensi yang tinggi dimana proses pembelajaran akan terlaksana dengan baik ketika guru mampu berperan dengan semestinya. Guru harus berinovasi dalam pembelajaran dimana hal ini dilakukan agar tercipta suasana belajar yang tidak membosankan. Guru berperan aktif dalam proses pembelajaran untuk mendatangkan kreativitas dan semangat belajar peserta didiknya.

Salah satu peran guru adalah dalam mengembangkan media pembelajaran. Dimana hal ini selaras dengan perkembangan teknologi yang semakin canggih.

\footnotetext{
${ }^{2}$ Itanur Hidayah, "Peran Guru Sebagai Fasilitator Pembelajaran Daring Pada MTs Di Kecamatan Tengaran Kabupaten Semarang Tahun 2020” (2020), http://e-repository.perpus.iainsalatiga.ac.id/9950/.
} 
Seharusnya dapat memudahkan pendidik dalam berkreativitas dalam proses pembelajaran. Adapun urgensi media dalam pembelajaran sebagai alat untuk membantu proses kegiatan belajar mengajar agar tujuan pembelajaran bisa dicapai dengan baik, juga memudahkan guru dalam penyampaian materi pembelajaran.

Berdasarkan pada pengamatan yang dilakukan penulis, beberapa sekolah menggunakan media pembelajaran daring berupa whatsapp, zoom, dan media lainnya seperti facebook, instagram dan sebagainya. Media ini dikatakan mampu untuk memfasilitasi pembelajaran daring, meskipun masih saja banyak peserta didik yang kurang respon dalam KBM. Juga dikarenakan beberapa hambatan yang muncul dari kesulitan media siswa yang tidak semua memiliki fasilitas belajar, selain itu juga terkendala sinyal dan semacamnya.

Informasi lain yang diterima dari Bapak Soni selaku Waka Kurikulum di SMKN 2 Purwakarta, beliau mengatakan pembelajaran online disana sudah dilaksanakan, namun dengan beberapa hambatan mengakibatkan pembelajaran tidak berjalan efektif. Salah satunya dikarenakan karena kurangnya pemahaman teknologi dari guru atau pengajar sehingga media pembelajaran tidak digunakan secara maksimal serta diperlukan juga tingkat kreativitas yang tinggi untuk guru dalam pengembangan media pembelajaran, karena memang sampai hari ini media pembelajaran daring masih memiliki hambatan dalam penggunaannya baik dari pihak guru atau sekolah maupun dari pihak siswa itu sendiri. Bapak soni juga mengatakan bahwa dengan wawasan mengenai media pembelajaran daring ini Juga masih minim, mengakibakan tingkat kreativitas dari masing-masing guru kurang terlihat. Pembelajaran masih monoton dan terlihat membosankan terlebih tanpa adanya tatap muka diperlukan suatu cara yang memang mampu menghubungkan atau menyamakan pandangan peserta didik atau penerima informasi dengan pendidik yang merupakan pemberi informasi. Diperlukan suatu alat atau media yang mampu memfasilitasi atau menjembatani proses pembelajaran daring tersebut.

Maka dari itu penelitian yang dilakukan penulis adalah terkait bagaimana peran guru dalam pengembangan media pembelajaran daring, adapun rumusan masalah dari penelitian ini antara lain: 1) Bagaimana Pengembangan media pembelajaran daring di SMKN 2 Purwakarta, 2) Bagaimana kelebihan pengembangan media pembelajaran guru PAIdBP di SMKN 2 Purwakarta, 3) Bagaimana kendala dan solusi guru dalam 
penyelesaian hambatan guru PAIdBP dalam pengembangan media pembelajaran daring di SMKN 2 Purwakarta.

Adapun tujuan penelitian ini adalah untuk mengetahui apa yang ditanyakan dalam rumusan masalah yang secara umum untuk mengetahui urgensi pengembangan media pembelajaran daring. Sehingga hal ini penting untuk dikaji dalam penelitian ini.

\section{B. Teori / Konsep}

\section{Pengembangan Media Pembelajaran}

Gagne mengatakan bahwa media pembelajaran adalah segala sesuatu yang dapat digunakan unuk mencapai pesan pembelajaran. Namun Asosiasi Pendidikan Nasional memiliki pengertian yang berbeda, menurutnya media adalah bentuk-bentuk komunikasi, baik yang tercetak maupun audio-visual serta peralatannya, Arief S. Sadirman dkk (2006:6). ${ }^{3}$

Media pendidikan sebagai salah satu sumber belajar yang dapat menyalurkan pesan sehingga membantu mengatasi kegagalan pembelajaran. Perbedaan gaya belajar, minat, intelegensi, keterbatasan daya indera, cacat tubuh, hambatan jarak geografis, jarak waktu dan lain lain dapat dibantu dengan pemanfaatan media pembelajaran. ${ }^{4}$

Dari berbagai pengertian yang disebutkan, pengertian media pembelajaran adalah segala seusatu yang dapat digunakan untuk menyampaikan pesan dari pengirim ke penerima, sehingga dapat merangsang pikiran, perasaan, perhatian dan minat serta semangat siswa sedemikian rupa sehingga proses belajar mengajar dapat dilaksanakan dengan baik. ${ }^{5}$

Adapun berbagai ragam dan bentuk media pembelajaran, pengelompokkan media dan sumber belajar dari taksonomi di atas dapat ditinjau dari jenisnya, yaitu dibedakan menjadi media audio, media visual, media audio-visual dan media serbaneka.

Daring merupakan akronim dalam jaringan, menurut KBBI Kemendikbud pusat, yang artinya terhubung melalui jejaring komputer, internet, dan sebagainya. Jadi kegiatan belajar mengajar guru, dosen, siswa, dan mahasiswa kini dilakukan secara

\footnotetext{
${ }^{3}$ Maswan and Khoirul Muslimin, Teknologi Pendidikan Penerapan Pembelajaran Yang Sistematis (Pustaka Pelajar, 2017).

${ }^{4}$ Ibid

${ }^{5}$ Ibid
} 
belajar daring termasuk saat pemberian tugas. ${ }^{6}$

Daring merupakan singkatan dari "dalam jaringan" sebagai pengganti kata online yang sering digunakan dalam kaitannya dengan teknologi internet. Daring adalah terjemahan dari istilah online yang bermakna tersambung ke dalam jaringan internet.

Pembelajaran daring merupakan pembelajaran yang dilakukan secara online, menggunakan aplikasi pembelajaran maupun jejaring sosial. Belajar daring adalah metode belajar yang menggunakan model interaktif berbasis internet dan learning manajemen system (LMS). Seperti mengguanakan Zoom, Google Meet, dan lainnya. Pembelajaran daring merupakan pembelajaran yang diselenggarakan melalui jejaring web. Setiap mata pelajaran menyediakan materi dalam bentuk rekaman video atau slideshow, dengan tugas-tugas mingguan yang harus dikerjakan dengan batas waktu pengerjaan yang telah ditentukan dan bebrapa sistem penilaian.

Dalam kamus besar bahasa Indonesia, pengembangan secara etimologi berasal dari kata kembang yang berarti menjadi tambah sempurna (tentang pribadi, fikiran, pengetahuan dan sebagainya). Pengembangan berarti proses, cara, perbuatan. Dan secara istilah, pengembangan merupakan suatu proses yang dipakai untuk mengembangkan dan memvalidasi produk pendidikan baik berupa proses, produk, dan rancangan. ${ }^{8}$

Adapun pengertian lain dari pengembangan adalah proses atau langkah yang dilakukan untuk membuat atau menyempurnakan sebuah produk yang sesuai dengan acuan kriteria produk yang dibuat.

Melihat dari pengertian perkata diatas, jadi pengertian pengembangan media pembelajaran daring adalah suatu proses yang digunakan dalam mengembangkan sebuah produk dengan memberikan rangsangan kepada siswa dalam proses pembelajaran yang dilakukan secara online atau tanpa tatap muka.

Dalam sebuah artikel juga dikatakan bahwa pengembangan media pembelajaran daring adalah serangkaian proses atau kegiatan yang dilakukan untuk menghasilkan suatu media pembelajaran daring berdasarkan teori pengembangan yang telah ada.

\footnotetext{
${ }^{6}$ R. Gilang K., Pelaksanaan Pembelajaran Daring Di Era Covid-19 (Lutfi Gilang, 2020).

${ }^{7}$ Ibid

${ }^{8}$ Kamus Besar Bahasa Indonesia, Tim Penyusun Kamus Pusat Pembinaan Dan Pengembangan Bahasa ((Jakarta: Balai Pustaka, 1989), n.d.).
}

6 | Paedagogie: P-ISSN: 2337-6848, E-ISSN: 2723-5971 
Media yang dimaksud adalah media pembelajaran sehingga teori pengembangan yang digunakan adalah teori pengembangan pembelajaran.

Suatu pengembangan media pembelajaran dapat dikatakan sebuah kreativitas dari pendidik itu sendiri dalam mengembangkan alat atau sumber dalam proses belajar mengajar.

Abdul Mustakim mengatakan bahwa "kreativitas sebagai daya cipta, kemampuan dan keinginan untuk selalu menciptakan halhal yang baru." Sedangkan Dilihat dari segi yang lain, kreativitas adalah proses yang digunakan seseorang untuk mempertunjukkan sifat dasarnya melalui suatu bentuk atau alat yang dirancang sedemikian rupa sehingga menimbulkan rasa puas bagi pembuatnya bahkan sampai menghasilkan sebuah produk yang mengkomunikasikannya kepada orang lain.

Banyak sekali model pengembangan multimedia pembelajaran yang ditawarkan oleh para pengembang. Stephen M. Alessi \& Stanley R. Trollip (1985) menawarkan 8 (delapan) langkah model pengembangan pembelajaran berbasis computer. Eleanor L. Criswell (1989) menawarkan 10 (sepuluh) langkah dalam mendesain, memproduksi dan mengevaluasi pembelajaran berbasis komputer. Andrian Mallon mengembangkan proses pengembangan multimedia. Rob Phillips (1997) menawarkan model pengembangan multimedia interaktif. Stephen M. Alessi \& Stanley R. Trollip (2001) menawarkan model desain dan pengembangan multimedia pembelajaran yang terdiri dari 3 (tiga) tahap. ${ }^{9}$

Adapun model proses pengembangan pembelajaran berbasis multimedia terbaru yang ditawarkan William W. Lee \& Diana L. Owens tahun 2004. Lee \& Owens merekomendasikan 5 (lima) tahap siklus pengembangan yang terdiri: analisis, desain, pengembangan, implementasi dan evaluasi.

Dari setiap media pembelajaran daring yang digunakan semuanya merupakan media berbasis IT, dan dalam ${ }^{10}$ dikatakan model pengembangan media berbasis IT, antara lain model Lee dan Owen, Model Thiagarajan, model Dick dan Carey dan lainlain. Salah satu model pengembangan media adalah model ADDIE. ADDIE adalah model perancangan instruksional yang berupa proses umum yang secara tradisional digunakan oleh perancang instruksional ataupun pengembangan pelatihan. Model

\footnotetext{
${ }^{9}$ Nunuk Suryani, "Pengembangan Media Pembelajaran Sejarah Berbasis It," Sejarah dan Budaya : Jurnal Sejarah, Budaya, dan Pengajarannya 10, no. 2 (2016): 186-196.

${ }^{10} \mathrm{Ibid}$
} 
ADDIE merupakan inti perancangan instruksional dan menjadi dasar sistem perancangan instruksional (Instructional System Design - ISD). Pada prakteknya terdapat beberapa macam adaptasi model ADDIE, tetapi secara umum terdiri dari 5 fase yang membentuk siklus yaitu Analysis, Design, Development, Implementation, dan Evaluation.

Ulasan yang dibuat Zulrahmat Togala untuk buku Instructional Design: The ADDIE Approach, menjelaskan aktivitas yang dilakukan pada masing-masing tahap sebagai berikut (Januszewski \& Molenda, 2008)

Analisis: pada fase analisis, dilakukan pendefinisian permasalahan instruksional, tujuan instruksional, dan sasaran pembelajaran. Pada fase ini juga dilakukan identifikasi atas lingkungan pembelajaran, pengetahuan dan keahlian yang saat ini sudah dimiliki oleh siswa. Fase ini dilakukan untuk menjawab pertanyaan-pertanyaan terkait hal-hal berikut : Siapa pemirsanya (audiens), apa yang perlu mereka pelajari, berapa anggarannya, opsi apa saja yang tersedia untuk menyajikan materi (delivery), kendala apa saja yang ada, kapan proyek harus selesai, dan apa yang harus dilakukan siswa untuk mengetahui kompetensi mereka.

Desain: fase desain terkait dengan penentuan sasaran, instrumen penilaian, latihan, konten, dan analisis yang terkait materi pembelajaran, rencana pembelajaran dan pemilihan media. Fase desain dilakukan secara sistematis dan spesifik. Aktivitas yang dilakukan pada tahap desain biasanya meliputi pemilihan lingkungan belajar yang paling sesuai dengan mempelajari jenis keahlian kognitif yang diperlukan untuk mencapai tujuan instruksional, menulis sasaran instruksional, memilih pendekatan secara keseluruhan, bentuk dan tampilan program : unit outline, pembelajaran dan modul, merancang materi kursus secara spesifik untuk digunakan pada medium elektronik interaktif.

Pengembangan (development): pada fase ini dilakukan pembuatan dan penggabungan aset konten yang sudah dirancang pada fase desain. Pada fase ini dibuat storyboard, penulisan konten dan perancangan grafis yang diperlukan. Jika melibatkan e-learning, programmer akan bekerja untuk mengintegrasikan teknologi yang diperlukan. Aktivitas yang dilakukan pada fase ini meliputi pembuatan atau pengumpulan media yang diperlukan, menggunakan kekuatan internet atau media elektronik untuk menyajikan informasi dalam berbagai format multimedia sehingga 
dapat memenuhi keinginan siswa, dan mendefinisikan interaksi yang sesuai, yang harus dalam bentuk kreatif, inovatif, dan mendorong siswa untuk terpancing belajar lebih lanjut.

Implementasi: pada fase ini, dibuat prosedur untuk pelatihan bagi peserta pelatihan dan instrukturnya / fasilitator. Pelatihan bagi fasilitator meliputi materi kurikulum, hasil pembelajaran yang diharapkan, metoda penyampaian dan prosedur pengujian. Aktivitas lain yang harus dilakukan pada fase ini meliputi penggandaan dan pendistribusian materi, handout dan bahan pendukung lainnya, serta persiapan jika terjadi masalah teknis dan mendiskusikan rencana alternatif dengan siswa.

Evaluasi: fase evaluasi terdiri atas dua bagian yaitu formatif dan sumatif. Evaluasi formatif terjadi di setiap tahapan proses ADDIE. Evaluasi sumatif terdiri atas test yang dirancang untuk domain yang terkait kriteria tertentu dan memberikan peluang umpan balik dari pengguna.

\section{Peran Guru dalam pengembangan Media Pembelajaran Daring}

Guru merupakan salah satu komponen dalam pembelajaran, dimana guru memiliki peran yang harus dilaksanakan dengan baik. Adapun yang dimaksud dengan peran yaitu seperangkat tingkat yang diharapkan, (dalam Kamus Besar Bahasa Indonesia, 2007.845). "peranan adalah bagian tugas utama yang harus dilaksanakan". Peranan adalah terciptanya serangkaian tingkah laku yang saling berkaitan yang dilakukan dalam suatu situasi tertentu serta berhubungan dengan kemajuan perubahan tingkah laku. ${ }^{11}$

Menurut Muhammad surya dalam bukunya psikologi guru konsep dan aplikasi, peran (role) guru merupakan keseluruhan perilaku yang dilakukan guru dalam melaksanakan tugasnya sebagai guru.

Menurut Sardiman (2008: 143-146) Sehubungan dengan fungsinya sebagai "pengajar", "pendidik", dan "pembimbing", maka diperlukan adanya peranan pada diri guru. Peranan guru ini akan senantiasa menggambarkan pola tingkah laku yang diharapkan dalam berbagai interaksinya, baik dengan siswa (yang terutama), sesama guru maupun staf yang lain.Dari berbagai kegiatan interaksi belajar mengajar, dapat dipandang sebagai sentral bagi peranannya. Sebab baik disadari atau tidak bahwa

\footnotetext{
${ }^{11}$ Siswa Di and Kelas V Sdn, "Peranan Guru Terhadap Pendidikan Karakter Siswa Di Kelas V Sdn 1 Siluman," PEDADIDAKTIKA: Jurnal Ilmiah Pendidikan Guru Sekolah Dasar 2, no. 2 (2015): 175-186. 
sebagian dari waktu dan perhatian guru banyak dicurahkan untuk menggarap proses belajar mengajar dan berinteraksi dengan siswanya. ${ }^{12}$

Guru tidak lah hanya bertugas sebagai pengajar yang memberikan materi pelajaran saja tetapi lebih dari itu, ada peran guru yang lain sebagai pembimbing, pengarah dan juga motivator kepada siswanya. Seorang guru juga harus mampu mengembangkan kualitas dirinya baik dari segi kepribadian maupun dalam cara mengajar seperti mengembangkan media pembelajaran bagi peserta didik, agar peserta didik dapat belajar dengan penuh semangat sehingga dapat mencapai tujuan pembelajaran.

Adapun dalam dijelaskan secara rinci peranan guru dalam kegiatan belajar mengajar, salah satunya sebagai mediator. ${ }^{13}$ Seorang guru dituntut memiliki pengetahuan dan pemahaman yang cukup tentang media pendidikan sebagai alat komunikasi dalam proses pembelajaran.

Guru harus terampil memilih, mengunakan, dan mengusahakan media pendidikan, serta mampu menjadi perantara (media) dalam hubungan antarsiswa dalam proses belajar mengajar.

Jadi berdasarkan uraian diatas berkenaan dengan pengembangan media pembelajaran yaitu harus memiliki pengetahuan dan wawasan yang luas mengenai media, yang nantinya guru harus mampu mengembangkan media pembelajaran agar diperoleh proses atau kegiatan belajar mengajar yang berkualitas dan menyenangkan.

Peran guru dalam mengembangkan media sangat diperlukan dalam proses belajar mengajar. Karena media merupakan alat yang membantu untuk mencapai tujuan pembelajaran. Guru harus mampu berinovasi dalam media pembelajaran yang digunakan, agar siswa mampu menyerap materi lebih mudah dan meningkatkan semangat dan minat belajar siswa. Maka dari itu dalam era perkembangan Iptek yang begitu pesat dewasa ini, guru tidak cukup hanya dengan kemampuan membelajarkan siswa, tetapi juga harus mampu mengelola informasi dan lingkungan untuk memfasilitasi kegiatan belajar siswa (Ibrahim, et.al., 2001). Dalam Kegiatan Belajar mengajar di dalam kelas, setiap siswa tentu memiliki intelegensi yang berbeda - beda

\footnotetext{
${ }^{12}$ Dkk Devi Arisanti, "Peran Guru Dalam Meningkatkan Aktivitas Belajar Siswa Pada Mata Pelajaran Sosiologi Di Kelas X Sma Pgri 1 Pontianak,” Angewandte Chemie International Edition, 6(11), 951-952. (1967): 1-11.

${ }^{13}$ Sadirman A. M, Interaksi Dan Motivasi Belajar Mengajar, 2011. 
baik laki - laki maupun perempuan, itulah sebabnya mengapa media pembelajaran sangat dibutuhkan dalam proses pembelajaran. Kelebihan perkembangan Iptek terhadap proses pembelajaran adalah diperkayanya sumber dan media pembelajaran, seperti buku teks, modul, overhead transparansi, film, video, televisi, slide, hypertext, web, dan sebagainya. Oleh sebab itu guru dituntut mampu memilih dan menggunakan berbagai jenis media pembelajaran yang ada di sekitarnya.

Adapun yang bisa dilakukan guru sebagai kendala dan solusi untuk mengatasi hambatan pengembangan media pembelajaran daring seperti yang dikatakan oleh Bramianto setiawan, adalah sebagai berikut:

1) Menetapkan strategi yang tepat

2) Perlu diadakan pelatihan

3) Diberikan pengalaman nyata

Media sebagai alat mengajar berkembang demikian pesatnya sesuai dengan kemajuan teknologi. Ragam dan jenis media pun cukup banyak sehingga dapat dimanfaatkan sesuai dengan kondisi, waktu, keuangan, maupun materi yang akan disampaikan.

Hal ini juga berkaitan erat dengan kondisi di abad 21 dimana setiap individu hidup dalam lingkungan yang tidak bisa dipisahkan dengan penggunaan teknologi, dimana seluruh aktivitas menjadi lebih mudah karena adanya kemudahan memperoleh informasi. Sehingga untuk mendukung kesuksesan di era digitalisasi sangat diperlukan basis keterampilan atau sebuah kreativitas atau pengembangan. Begitu juga dalam proses bempelajaran yang mana harus disesuaikan dengan perkembangan zaman, termasuk pada media pembelajaran yang digunakan.

Kecakapan abad 21 secara global dijabarkan dalam 4 kategori sebagai berikut: (a) Cara berpikir: Kreatifitas dan inovasi, berpikir kritis, memecahkan masalah, mengambil keputusan, dan belajar untuk belajar; (b) Cara untuk bekerja: Berkomunikasi dan bekerja sama; (c) Alat untuk bekerja: Pengetahuan umum dan keterampilan teknologi informasi dan komunikasi; (d) Cara untuk hidup: karir, tanggung jawab pribadi dan social termasuk kesadaran akan budaya dan kompetensi.

Meski dalam kurikulum keterampilan tidak memiliki posisi yang khhusus namun pendidikan di abad 21 ini memiliki aspek keterampilan dan pemahaman, hal ini terdapat pada penekanan kreativitas yang harus ada dalam proses pembelajaran. 
Beberapa juga melibatkan teknologi, tingkah laku dan nilai nilai moral, selain itu juga menekankan pada keterampilan berpikir kritis dan berkomunikasi yang lebih memberikan tantangan dalam proses. Lebih lanjut keterampilan abad 21 tersebut dirangkum dalam sebuah skema yang disebut dengan pelangi keterampilan pengetahuan abad 21 atau 21st century knowledge-skills rainbow.

Kecakapan abad 21 merupakan sebab seorang pendidik harus mengubah pola pikirnya. Kenyataan yang ada dilapangan bahwa pendidik hari ini jauh berbeda dengan pendidik jaman dahulu. Dulu banyak diantara guru yang memang bermodal keikhlasan dalam mengajar serta semata-mata untuk mengabdi pada negara sehingga dapat mencetak peserta didik yang teguh dan menjadi manusia yang memiliki nilai dalam hidupnya. Sedangkan, pendidik hari ini kebanyakan hanya sebatas mengajar dan memberikan materi yang selanjutnya tidak jarang menindak lanjuti perubahan sikap atau nilai diri pada peserta didik. Kebanyakan proses pembelajaran dilakukan hanya untuk menggugurkan kewajibannya saja sebagai seorang pengajar. Menjadi pendidik yang profesional bukan semata-mata hanya dilihat dari keahlian menyampaikan materi, tetapi lebih dari itu pendidik harus mendampingi siswa untuk setiap penemuan atau perubahan dalam proses pembelajaran. ${ }^{14}$

Kecakapan abad 21 merupakan sebuah konsep yang mampu menjadi pemicu timbulnya semangat bagi para pendidik untuk mengembangkan proses pembelajaran yang nantinya dapat menghasilkan peserta didik yang mampu menghadapai tantangan kehidupan di era digitalisasi abad 21 ini. Pendidik dituntut agar mengubah setiap proses yang tidak lagi cocok digunakan dalam pembelajaran, pendidik harus mampu membuat proses pembelajaran menjadi begitu menyenangkan dengan memanfaatkan perkembangan digital yang semakin melaju pesat sehingga mampu memenuhi kebutuhan siswa.

Abad 21 dengan perkembangan teknologi senantiasa menyediakan akses mudah kepada peserta didik dalam proses pembelajarannya. Berangkat dari hal inilah pendidik memiliki tugas untuk dapat membuat desain belajar yang memungkinkan anak didik

\footnotetext{
${ }^{14}$ Rayinda Dwi Prayogi and Rio Estetika, "Kecakapan Abad 21 : Kompetensi Digital Pendidik Masa Depan," Jurnal Manajemen Pendidikan 14, no. 2 (2019): 148,

http://journals.ums.ac.id/index.php/jmp/article/view/9486.

${ }^{15}$ Maswan and Muslimin, Teknologi Pendidikan Penerapan Pembelajaran Yang Sistematis. ${ }^{16}$ Sugiyono, Metode Penelitian Pendidikan Pendekatan Kuantitatif, Kualitatif,Dan R\&D (ALFABETA, cv, 2010).
} 
mampu mengembangkan potensi literasinya untuk menyelesaikan masalah yang kompleks dan menjadi pembelajaran bermakna hingga sepanjang hidup.

Kompetensi Digital Pendidik Abad 21 erat kaitannya dengan kecakapan pendidik dalam menggunakan teknologi informasi dan komunikasi berdasarkan kaidah pedagogis dengan menyadari implikasinya terhadap metodologi pendidikan. Tetyana Blyznyuk membagi kompetensi digital pendidik kedalam beberapa bentuk, yaitu: information, communication, edicational content creation, security educational problem solving.

Kaitan peran guru sebagai mediator atau pengembangan media pembelajaran daring dengan kecakapan abad 21 ini erat hubungannya, sehingga sebagai pendidik yang baik kita harus selalu memperbaharui diri dan kualitas, jangan monoton atau teguh pendirian dalam kesalahan. Pendidik harus terus belajar, karena belajar merupakan salah satu keharusan dalam proses pendidikan.

\section{Metode Penelitian}

Pendekatan dalam penelitian ini menggunakan pendekatan kualitatif, yaitu pendekatan dikenal sebagai penelitian ilmiah yang menekankan pada karakter alamiah sumber data. Sedangkan penelitian kualitatif menurut Sugiyono merupakan penelitian yang berdasarkan pada filsafat postpositivisme, yang digunakan guna meneliti kondisi sasaran yang alamiah. Metode Kualitatif adalah sebuah metode yang mencoba untuk mendapatkan sebuah pemahaman yang lebih baik lagi mengenai kompleksitas yang ada dalam interaksi manusia. ${ }^{16}$

Dengan metode kualitatif ini, peneliti akan mendapatkan data atau informasi secara lebih mendalam. Selain itu pemilihan metode kualitatif ini didasarkan atas alasan ingin memaknai sesuatu dan mencari keunikan tentang peran guru dalam pengembangan media pembelajaran daring dimana permasalahan ini masih belum jelas, kompleks, dan dinamis sehingga tidak mungkin data pada situasi seperti ini diteliti menggunakan metode kuantitatif yang berbagai alatnya seperti tes, kuesioner dan lainlain. Serta peneliti bermaksud untuk menemukan pola, hipotesis, dan teori yang bisa diteliti dengan alat pada penelitian kualitatif, untuk pemahaman masalah atau situasi

\footnotetext{
${ }^{16}$ Sugiyono, Metode Penelitian Pendidikan Pendekatan Kuantitatif, Kualitatif,Dan R\&D (ALFABETA, cv, 2010).
} 
secara detail dan mendalam. ${ }^{17}$

Adapun dalam pelaksanaan penelitian ini, kedudukan peneliti adalah sebagai pengamat penuh atau sebagai partisipasi lengkap yang mana peneliti dalam proses pengumpulan data, peneliti terlibat langsung secara penuh kepada apa yang dilakukan oleh sumber data. ${ }^{18}$ Dengan demikian ini memudahkan dalam mengamati informan dan mendapatkan sumber data secara langsung sehingga data peroleh benar benar ada nyatanya. Berkaitan dengan pengumpulan data dari sumbernya peneliti memaksimalkan hubungan atau interaksi dengan narasumber sehingga tercipta keadaan atau kondisi yang baik dengan informan, hal ini guna memperoleh data yang akurat dan lengkap. Pada tahap awal penelitian, peneliti terlebih dahulu mengumpulkan data sebanyak-banyaknya dengan cara Observasi dan dokumentasi, kemudian melakukan wawancara dengan kepala sekolah yang diwakili oleh WAKA Kurikulum dan guru PAIdBPPenelitian ini termasuk penelitian lapangan. Teknik pengumpulan data dengan cara mendatangi langsung tempat yang menjadi objek penelitian untuk memperoleh data sesuai kebutuhan penulis. Adapun cara pengumpulan data menggunakan teknik observasi (pengamatan), wawancara, dan dokumentasi. ${ }^{19}$

Pada penelitian ini, peneliti menggunakan sumber data primer dan sekunder dimana sumber data yang dipilih awal tentunya berkaitan langsung dengan masalah penelitian yaitu guru PAIdBP, Selain data primer, peneliti juga akan menggunakan data sekunder dimana tentunya data tersebut menjadi pendukung kedalaman informasi mengenai permasalahan yang akan diteliti yaitu dari Waka Kurikulum dan dokumen penunjang.

Analisis data penelitian ini bersifat induktif, yaitu suatu analisis berdasarkan data yang diperoleh, kemudian dikembangkan menjadi pola hubungan tertentu atau menjadi penemuan hipotesis. ${ }^{20}$ Peran guru dalam proses pembelajaran sangat banyak salah satunya adalah menciptakan suasana belajar yang menyenangkan dengan pemilihan media pembelajaran yang tepat. Dalam penelitian ini diambil peran guru dalam pengembangan media pembelajaran daring.

Analisis hasil wawancara dengan berbagai sumber data, peneliti menggunakan

\footnotetext{
${ }^{17}$ Ibid.

18 Ibid.

19 Ibid.

20 Ibid 
metode analisis data Miles dan Huberman yang meliputi reduksi data, penyajian data, dan penarikan kesimpulan. ${ }^{21}$

Adapun cara pengujian keabsahan data penelitian ini yaitu dengan perpanjangan pengamatan, trianggulasi, dan diskusi dengan teman sejawat.

\section{Hasil Penelitian dan Pembahasan}

\section{Hasil Penelitian}

Setelah melakukan proses penelitian melalui teknik pengamatan, dokumentasi dan wawancara peneliti menemukan beberapa informasi dilapangan terkait pengembangan media pembelajaran daring yang dilakukan di SMKN 2 Purwakarta.

Adapun pengembangan media visual, ibu Tati mengatakan beliau menggunakan slide pembelajaran berupa gambar bergerak tanpa suara, pengembangan yang dilakukan dalam media visual ini adalah dengan mengembangkan kreatif dari guru itu sendiri terkait materi pembelajaran atau kreativitas dalam pembuatan slide pembelajarannya.

Sedangkan informasi dari Pak imar, beliau sangat senang menggunakan media visual berupa gambar, dimana pak imar membuat gambarnya sendiri dengan manual atau melalui bantuan komputer.

Secara keseluruhan pengembangan media pembelajaran daring yang dilakukan oleh guru PAIdBP di SMKN 2 Purwakarta adalah dengan optimalisasi google workspace, dimana gogle workspace ini difasilitasi oleh akun belajar.id yang sudah disediakan pemerintah.

Menurut penuturan Ibu Tati google workspace ini merupakan media dan teknologi pembelajaran yang disediakan secara gratis oleh google dengan memanfaatkan akun belajar.id teknologi dapat kita gunakan secara bebas dengan terlebih dahulu mengunduh akun belajar.id yang melalui aplikasi dapodik sekolah. Sebenarnya media pembelajaran ini merupakan media yang harus berbayar namun berkat kerjasama antara google indonesia dengan kementerian pendidikan dan kebudayaan seluruh aplikasi tersebut dapat digunakan secara gratis hanya dengan menggunakan akun belajar.id.

Selanjutnya informasi ini dikuatkan dengan yang disampaikan ibu Nopi terkait penggunaan google workspace ini adalah dengan memanfaatkan fitur-fiturnya sepeti

${ }^{21}$ Ibid 
google classrom colaboratif, google drive, g-mail, Google Sheets, Google Formulir, Google Slides, Google Gambar dan lain sebagainya.

Dan lebih jelasnya, pak Soni selaku Waka Kurikulum kembali menuturkan tentang google workspace ini awalnya dibuat untuk badan usaha dengan prinsip berbayar langganan. Untuk kepentingan pendidikan, Google berniat menggratiskan Google Worksapce for Education. Namun tidak sembarang orang dapat menggunakannya. Persyaratan yang mesti dipenuhi untuk mendapatkan akses gratis.

Informasi lain terkait pengunaan media ini juga disampaikan oleh Pak Soni selaku Waka Kurikulum di SMKN 2 Purwakarta, beliau mengatakan bahwa optimalisasi penggunaan media google workspace adalah peningkatan kepedulian dari pemerintah apalagi dengan fasilitas belajar.id yang disediakan pemerintah itu sangat membantu dalam bidang pendidikan khususnya dalam proses belajar mengajar yang dilakukan.

Proses pembelajaran yang dilakukan dengan google workspace ini memiliki alur yang sistematis jadi lebih memudahkan dalam KBM yang dilakukan secara online. Adapun langkah yang dilakukan dalam pengembangan ini menurut Ibu Tati, pertama dengan menganalisis kebutuhan pembelajaran, seperti karakteristik peserta didik, juga menganalisis tujuan pembelajaran serta menganalisis keadaan atau situasi belajar. Langkah kedua adalah tahap design, pada tahap design ini pendidik merancang setiap proses pembelajaran dari mulai kegiatan awal sampai kegiatan penutupan pembalajaran bahkan sampai evaluasi pembelajaran juga mulai ada pemilihan media yang akan digunakan atau fitur yang akan digunakan dalam pembelajaran, jadi dalam tahap ini disusun RPP yang baik. Langkah selanjutnya adalah melakukan apa yang sudah disusun dalam RPP dengan pemanfaatan media google workspace yang memiliki banyak fitur. Setelah itu pendidik mencatat kelebihan kekurangan dan melakuakn pemberian tes untuk dijadikan alat pengukur keberhasilan. Dan terakhir adalah tahap kelayakan penggunaan media pembelajaran google workspace.

Berdasarkan informasi secara keseluruhan pengembangan media pembelajaran daring yang dilakukan guru PAIdBP di SMKN 2 Purwakarta adalah dengan optimalisasi penggunaan media google workspace dengan fasilitas akun belajar.id yang di sediakan kemendkbud juga penggunaan multiedia pembelajaran daring atau kolaborasi media pembelajaran. 
Adapun informasi pertama yang diperoleh dari Bapak Tirwan, beliau mengatakan dengan adanya pengembangan ini, banyak kelebihan yang dirasakan juga pada proses pembelajaran. Beliau merasa proses pembelajaran menjadi lebih mudah, meski tanpa tatap muka karena alur pembelajaran yang tersusun, sehingga tingkat efektivitas serta efisiensi menjadi lebih tinggi.

Hal ini disetujui oleh Ibu Tati yang mengatakan bahwa penggunaan media google workspace ini bisa membantu pendidik dalam berjalannya proses KBM, peserta juga jadi lebih aktif dan antusias dalam proses pembelajaran.

Adapun kelebihan lain yang dirasakan dengan adanya pengembangan media pembelajaran dari melalui google workspace ini, peserta didik jadi lebih bisa mengembangkan dirinya melalui penugasan yang diberikan. Peserta didik dengan penggunaan google workspace ini juga menjadi lebih inisiatif dalam pembelajaran, ditambah kolaborasi media yang digunakan juga menjadi pemicu anak-anak menemukan hal-hal baru. Seperti dalam kegiatan yang seringkali melibatkan penggunaan internet, akhirnya siswa menemukan hal lain diluar materi pembelajaran.

Banyak sekali kelebihan yang dihasilkan dari pengembangan media pembelajaran daring ini dengan menggunakan google workspace. Ibu Nopi mengatakan bahwa dengan adanya penggunaan media seperti ini pembelajaran menjadi lebih menyenangkan, tidak monoton.

Proses pembelajaran juga menjadi lebih produktif serta berkualitas. Fitur fitur yang ada dalam google wokspace ini juga dapat dijdikan sarana untuk mengembangkan kreativitas pendidik. Pendidik menjadi lebih semangat untuk menciptakan proses belajar yang semakin membuat anak semangat dalam belajar, sehingga ada peningkatan hasil belajar dari peserta didik. Adapun penggunaan media pembelajaran seperti ini menggunakan beberap fitur atau mengkolaborasikan media pembelajaran, menjadikan pembelajaran semakin memiliki keluasan dan keleluasaan dalam kegiatannya. Tidak hanya itu ini mendorong adanya proses pembelajaran yang akan berkelanjutan, artinya dapat dilakukan dimana saja, dan kapan saja.

Bapak Imar juga mengatakan bahwa dengan adanya kemajuan teknologi yang semakin mengarah ke hal positif dapat mengurangi pandangan bahwa penggunaan internet atau sejenisnya adalah pengaruh yang negatif. Hal tersebut tidak akan terjadi dengan pengembangan media pembelajaran daring ini karena proses KBM kian 
membaik dengan adanya kemajuan digitalisasi.

Adapun bapak Tirwan menyampaikan bahwa penggunaan media pembelajaran daring ini juga memberi kelebihan pada nilai yang semakin meningkat dari penggunaan media pembelajaran daring yang biasa.

Kelebihan adanya pengembangan media pembelajaran daring dengan optimalisasi penggunaan gogle workspace ini ada banyak sekali dan memang sangat memberi pengaruh besar bagi proses pembelajaran serta peningkatan kualitas diri pendidik dan peserta didik.

Berdasarkan informasi yang diperoleh secara keseluruhan, banyak sekali kelebihan pengembangan media pembelajaran daring di SMKN 2 Purwakarta. Kendala dan solusi guru dalam menyelesaikan hambatan pengembangan media pembelajaran daring di SMKN 2 Purwakarta.

Pengembangan media pembelajaran daring memang bukanlah hal yang mudah, terutama bagi pendidik yang sudah tidak muda lagi, ini menjadi tantangan yang cukup berat.

Beberapa kesulitan dirasakan oleh guru PAIdBP, terkait pemahaman yang juga harus banyak tentang media pembelajaran daring ini. Sedangkan bapak tirwan mengatakan bahwa dirinya memang sangat minim sekali pengetahuan tentang media pembelajaran daring, yang beliau paham hanya sebatas media belajar seperti biasa tatap muka.

Adapun dalam penuturan tersebut, pak tirwan akan selalu belajar untuk selalu menambah wawasan pengetahuan tentang media pembelajaran daring ini, dan hal tersebut merupakan salah satu kendala dan solusi yang dilakukam guru dam mengatasi hambatan pengembangan media pembelajaran daring.

Dari berbagai infromasi yang ada, beberapa solusi dilakukan oleh guru PAIdBP di SMKN 2 Purwkarta adalah dengan menambah wawasan atu pengetahuan tentang pengembangan media pembelajaran daring melalui proses belajar yang tanpa henti, pembiasaan penggunan medi pembeljaran, penyediaan fasilitas belajar yang semakin menunjang pembelaran, juga ikut serta dalam kegiatan pelatihan atau webinar yang berkenaan dengan pengembangan media pembelajaran, serta bertukar pikiran dengan teman guru di sekolah lain sebagai pengalaman pembelajaran. 


\section{Analisis Data}

Berdasarkan hasil penelitian yang dilakukan, dalam pengembangan media pembelajaran daring ini Sesuai dengan Teori jenis media yang dapat digunakan dalam pembelajaran. Seperti Media audio, media visual, media audio visual dan media serbaneka yang dalam pengembangan nya digunakan media google workspace dengan fasilitas akun belajar. Id dari Pemerintah, dimana dalam proses Pengembangannya merujuk pada teori pengembangan media pembelajaran berbasis IT model ADDIE, dengan beberapa proses yaitu sebagai berikut: ${ }^{22}$

Pertama tahap analisis (A): pada fase analisis, dilakukan pendefinisian permasalahan instruksional, tujuan instruksional, dan sasaran pembelajaran. Pada fase ini juga dilakukan identifikasi atas lingkungan pembelajaran, pengetahuan dan keahlian yang saat ini sudah dimiliki oleh siswa. Sebagaimana disampaikan oleh Ibu Tati terkait langkah ini, beliau melakukan beberapa hal berikut: guru mengidentifikasi kebutuhan pembelajaran baik dari segi siswa ataupun proses pembelajaran.

Adapun yang dilakukan Ibu Tati secara rinci adalah sebagai berikut:

a. Menentukan karakteristik peserta didik

b. Menganalisis kebutuhan bahan ajar

c. Menentukan jenis media yang akan dikembangkan

d. Menganalisis kendala yang ditemukan

e. Merancang penilaian untuk peserta didik serta batas waktu dalam menyelesaikan tugas.

Kedua, tahap desain (D) dimana fase desain terkait dengan penentuan sasaran, instrumen penilaian, latihan, konten, dan analisis yang terkait materi pembelajaran, rencana pembelajaran dan pemilihan media. Fase desain dilakukan secara sistematis dan spesifik. Aktivitas yang dilakukan pada tahap desain biasanya meliputi pemilihan lingkungan belajar yang paling sesuai dengan mempelajari jenis keahlian kognitif yang diperlukan untuk mencapai tujuan instruksional, menulis sasaran instruksional, memilih pendekatan secara keseluruhan, bentuk dan tampilan program : unit outline, pembelajaran dan modul, merancang materi kursus secara spesifik untuk digunakan pada medium elektronik interaktif. hal ini sesuai dengan yang dikatakan ibu Tati, beliau melakukan beberapa kegiatan dalam tahap kedua ini yang dituangkan dalam Rencana pelaksanaan pembelajaran dengan menyusun tujuan pembelajaran, kemudian

${ }^{22}$ Suryani, "Pengembangan Media Pembelajaran Sejarah Berbasis It." 
menentukan strategi pembelajaran yang tepat untuk mencapai tujuan tersebut. Penentuan metode pembelajaran dan pemilihan media pembelajaran yang mana dalam google workspace ini menyediakan banyak fitur seperti google meet, google classroom dan lain sebagainya. Dengan mempertimbangkan beberapa aspek seperti sumber belajar yang relevan, lingkungan belajar dan lain-lain. Adapun RPP yang dimaksud terdapat pada lampiran.

Ketiga, tahap development (D), pada fase ini dilakukan pembuatan dan penggabungan aset konten yang sudah dirancang pada fase desain. Pada fase ini dibuat storyboard, penulisan konten dan perancangan grafis yang diperlukan. Jika melibatkan e-learning, programmer akan bekerja untuk mengintegrasikan teknologi yang diperlukan. Aktivitas yang dilakukan pada fase ini meliputi pembuatan atau pengumpulan media yang diperlukan, menggunakan kekuatan internet atau media elektronik untuk menyajikan informasi dalam berbagai format multimedia sehingga dapat memenuhi keinginan siswa, dan mendefinisikan interaksi yang sesuai, yang harus dalam bentuk kreatif, inovatif, dan mendorong siswa untuk terpancing belajar lebih lanjut. Sebagaimana penuturan masih dari Ibu tati bahwa setelah merancang desain lalu tahap berikutnya adalah melakukan proses pembelajaran daring . pada tahap ini dikembangkan proses pembelajaran dengan media google workspace yang difasilitasi akun belajar.id. Dengan menganalisis apa yang harus dilakukan pengguna media tersebut. Adapun pengguna yang terhubung antara lain Waka kurikulum, guru PAIdBP, guru mapel lain, dan siswa itu sendiri. Adapun tugas Waka Kurikulum adalah untuk mengawasi proses pembelajaran dan menilai kinerja guru, lalu untuk guru bertugas meng-upload materi, memberikan tugas, menilai tugas, dan memantau perkembangan pembelajaran siswa. Siswa dapat melihat materi, meng-upload tugas, berdiskusi dalam forum. Dan guru mapel lain hanya Dapat melihat materi tanpa ikut serta.

Keempat, tahap implementasi (I): pada fase ini, dibuat prosedur untuk pelatihan bagi peserta pelatihan dan instrukturnya / fasilitator. Pelatihan bagi fasilitator meliputi materi kurikulum, hasil pembelajaran yang diharapkan, metoda penyampaian dan prosedur pengujian. Aktivitas lain yang harus dilakukan pada fase ini meliputi penggandaan dan pendistribusian materi, handout dan bahan pendukung lainnya, serta persiapan jika terjadi masalah teknis dan mendiskusikan rencana alternatif dengan siswa. Dari teori diatas, sesuai dengan yang dikatakan ibu Tati, langkah selanjutnya 
adalah guru membuat catatan tentang kekurangan dan kendala yang masih terjadi ketika penggunaan media google workspace ini digunakan dalam pembelajaran selain itu peserta didik juga diberikan soal tes setelah penggunaan media untuk mengetahui keberhasilan media pembelajaran dengan google workspace ini.

Kelima tahap evaluasi (E): fase evaluasi terdiri atas dua bagian yaitu formatif dan sumatif. Evaluasi formatif terjadi di setiap tahapan proses ADDIE. Evaluasi sumatif terdiri atas test yang dirancang untuk domain yang terkait kriteria tertentu dan memberikan peluang umpan balik dari pengguna. Teori ini juga sesuai dengan yang dikatakan oleh Ibu Tati bahwa beliau melakukan analisis penilaian yang sudah dilakukan dalam tahap implementasi, dan bu tati mengatakan bahwa penggunaan media google workspace ini layak diterapkan karena adanya peningkatan nilai belajar dari siswa dan bisa mewujudkan tujuan pembelajaran.

Jadi dari informasi yang ada dapat dikatakan bahwa pengembangan media pembelajaran daring yang dilakukan di SMKN 2 purwakarta yaitu menggunakan model pengembangan ADDIE dengan Optimalisasi penggunaan media google workspace difasilitasi akun belajar. Id.

Adapun kelebihan yang dihasilkan setelah adanya pengembangan media pembelajaran dengan optimalisasi penggunaan media Google workspace dengan fasilitas akun belajar. Id adalah sesuai dengan teori yang disampaikan oleh sebagai kelebihan adanya pengembangan media pembelajaran adalah sebagai berikut: Meningkatkan efektivitas dan efisiensi dalam pembelajaran, Peserta didik mampu menciptakan sesuatu yang baru, Mendorong Peserta didik dalam mengekspresikan gagasan, Mendorong guru untuk lebih kreatif, Memperluas kesempatan belajar, Meningkatkan kualitas belajar mengajar, Memfasilitasi pembentukan keterampilan, Mendorong belajar sepanjang hayat berkelanjutan, Meningkatkan perencanaan kebijakan dan manajemen, Mengurangi kesenjangan digital.

Adapun paparan mengenai kendala dalam pengembangan media pembelajaran daring adalah kurangnya pemahaman atau pengetahuan guru terkait pengembangan media pembelajaran daring dan solusi guru dalam penyelesaian kendala guru dalam pengembangan media pembelajaran daring, berdasarkan teori yang disebutkan dalam BAB II, antara lain: Menetapkan strategi yang tepat, Pengadaan pelatihan, Pemberian pengalaman nyata. 


\section{E. Penutup}

Berdasarkan penelitian yang sudah dilakukan oleh penulis tentang peran guru dalam pengembangan media pembelajaran daring di SMK Negeri Purwakarta, maka terdapat beberapa hal yang dapat disimpulkan, adalah sebagai berikut: Pengembangan media pembelajaran daring di SMKN 2 Purwakarta sudah sesuai dengan model pengembangan ADDIE dengan optimalisasi penggunaan media google workspace dengan fasilitas akun belajar.id yang disediakan kemendikbud yang melalui tahap pengembangan sebagai berikut. Kelebihan Pengembangan media pembelajaran daring di SMKN 2 Purwakarta antara lain : 1) meningkatkan efektivitas dan efisiensi dalam pembelajaran, 2) peserta didik mampu menciptakan sesuatu yang baru, 3) mendorong peserta didik dalam mengekspresikan gagasan, 4) mendorong guru untuk lebih kreatif, 5) memperluas kesempatan belajar, 6) meningkatkan kualitas belajar mengajar, 7) memfasilitasi pembentukan keterampilan, 8) mendorong belajar sepanjang hayat berkelanjutan, 9) meningkatkan perencanaan kebijakan dan manajemen, 10) mengurangi kesenjangan digital. Kendala pengembangan media adalah kurangnya pengetahuan terkait media.

Pembelajaran daring, dan solusi guru dalam penyelesaian kendala pengembangan media pembelajaran daring di SMKN 2 Purwakarta adalah dengan cara 1) Terus belajar, membiasakan diri menggunakan media daring, serta ikut serta dalam kegiatan webinar atau semacamnya tentang pengembangan media pembelajaran daring, 2) mengadakan pelatihan dalam kegiatan IHT serta pelatihan terkait pembuatan video animasi dalam rangka pengembangan media pembelajaran daring, 3) melakukan sharing ilmu dan pengalaman dengan guru di sekolah lain tentang pengembangan media pembelajaran daring.

Adapun saran bagi sekolah diharapkan mampu menjadi tempat yang baik bagi setiap komponennya. Begitu juga dalam hal fasilitas atau media pembelajaran, yang merupakan salah satu kebutuhan dalam proses pembelajaran. Maka sekolah atau lembaga harus mampu menyediakan fasilitas, saraya dan segala seusatu yang dibutuhkan dalam proses pembelajaran agar tujuan pendidikan dapat diwujudkan dengan baik. Sedangkan untuk pendidik seyogiyanya harus memiliki kualifikasi dan kualitas diri yang baik. Pendidik diharapkan mampu mengembangkan pembelajaran dengan sedemikian rupa yang nantinya menghasilkan peserta didik yang bukan hanya 
bagus nilai angka saja tetapi baik dalam kualitas dirinya juga. Serta bagi peserta didikpembelajaran daring ini memberi kesempatan kepada setiap pembelajar untuk semakin kreatif dan inovatif dalam pembelajaran. Perkembangan media pembelajaran yang ada, diharapkan mampu membangkitkan semangat dan daya hidup peserta didik dalam proses pembelajaran. Kamu peran utamanya, masa depan adalah milik kalian semua.

\section{DAFTAR PUSTAKA}

Devi Arisanti, Dkk. "Peran Guru Dalam Meningkatkan Aktivitas Belajar Siswa Pada Mata Pelajaran Sosiologi Di Kelas X Sma Pgri 1 Pontianak.” Angewandte Chemie International Edition, 6(11), 951-952. (1967): 1-11.

Di, Siswa, and Kelas V Sdn. "Peranan Guru Terhadap Pendidikan Karakter Siswa Di Kelas V Sdn 1 Siluman.” PEDADIDAKTIKA: Jurnal Ilmiah Pendidikan Guru Sekolah Dasar 2, no. 2 (2015): 175-186.

Hidayah, Itanur. "Peran Guru Sebagai Fasilitator Pembelajaran Daring Pada MTs Di

Kecamatan Tengaran Kabupaten Semarang Tahun 2020" (2020). http://e repository.perpus.iainsalatiga.ac.id/9950/.

Indonesia, Kamus Besar Bahasa. Tim Penyusun Kamus Pusat Pembinaan Dan Pengembangan Bahasa. (Jakarta: Balai Pustaka, 1989), n.d.

Maswan, and Khoirul Muslimin. Teknologi Pendidikan Penerapan Pembelajaran Yang Sistematis. Pustaka Pelajar, 2017.

Pengelola web kemdikbud. "Kemendikbud Terbitkan Kurikulum Darurat Pada Satuan Pendidikan Dalam Kondisi Khusus.” Kemdikbud.Go.Id. Last modified 2020. Accessed June 25, 2021.

https://www.kemdikbud.go.id/main/blog/2020/08/kemendikbud-terbitkan kurikulum-darurat-pada-satuan-pendidikan-dalam-kondisi-khusus. Prayogi, Rayinda Dwi, and Rio Estetika. "Kecakapan Abad 21 : Kompetensi Digital Pendidik Masa Depan.” Jurnal Manajemen Pendidikan 14, no. 2 (2019): 148.

http://journals.ums.ac.id/index.php/jmp/article/view/9486.

R. Gilang K. Pelaksanaan Pembelajaran Daring Di Era Covid-19. Lutfi Gilang, 2020. Sadirman A. M. Interaksi Dan Motivasi Belajar Mengajar, 2011. 
Pedagogie, Vol. 3. No. 1 Januari 2022, $01-24$

Sugiyono. Metode Penelitian Pendidikan Pendekatan Kuantitatif, Kualitatif,Dan R\&D.

ALFABETA, cv, 2010.

Suryani, Nunuk. "Pengembangan Media Pembelajaran Sejarah Berbasis It." Sejarah dan Budaya: Jurnal Sejarah, Budaya, dan Pengajarannya 10, no. 2 (2016): 186- 196. 